\title{
RESCUE OF Cucurbita spp. GERMPLASM IN RIO GRANDE DO NORTE ${ }^{1}$
}

\author{
GRACE KELLY LEITE DE LIMA ${ }^{2 *}$, MANOEL ABILIO DE QUEIRÓZ ${ }^{3}$, LINDOMAR MARIA DA SILVEIRA²
}

\begin{abstract}
In order to rescue Cucurbita spp. germplasm from family farming in the state of Rio Grande do Norte, to quantify the phenotypic variability and identify the main species grown, 17 expeditions were organised to collect accessions in the municipalities of Baraúna, Rio do Fogo and Touros (major fruit suppliers to the state trade) and in eight more municipalities in different regions of the state (Apodi, Caraúbas, Ceará Mirim, Cerro Corá, Currais Novos, João Câmara, Lagoa Nova and Macaíba). Each collected accession consisted of a fruit or about 20 seeds provided directly by the farmer. All accessions were identified according to botanical species, and packaging procedures, identification and seed storage in the cold for preservation were performed. A sample of collected accessions, consisting of fruit and a small number of accessions obtained as C. moschata seeds, was multiplied using self-fertilisation of plants. Plants and fruits were characterised preliminarily with the aid of morphological descriptors. Accessions were rescued in all visited municipalities 112 of $C$. moschata and 50 of C. maxima. There was a predominance of $C$. moschata species cultivation, and great variability was found in various plant and fruit descriptors in the accessions characterised.
\end{abstract}

Keywords: C. moschata. C. maxima. Accessions Collection. Variability.

\section{RESGATE DE GERMOPLASMA DE Cucurbita spp. NO RIO GRANDE DO NORTE}

RESUMO - Com objetivo de resgatar germoplasma de Cucurbita spp. da agricultura familiar do estado do Rio Grande do Norte, quantificar a variabilidade fenotípica e identificar as principais espécies cultivadas, foram organizadas 17 expedições para coleta de acessos, nos municípios de Baraúna, Rio do Fogo e Touros (principais fornecedores de frutos para o comercio estadual) e de mais oito municípios de diferentes microrregiões do Estado (Apodi, Caraúbas, Ceará Mirim, Cerro Corá, Currais Novos, João Câmara, Lagoa Nova e Macaíba). Cada acesso coletado foi composto por um fruto ou aproximadamente vinte sementes fornecidas pelo próprio agricultor. Todos os acessos foram identificados quanto à espécie botânica e realizados os procedimentos de acondicionamento, identificação e armazenamento das sementes em câmara fria para preservação do material. Uma amostra dos acessos coletados como frutos e uma pequena parte dos acessos obtidos como sementes da espécie C. moschata foram multiplicados usando-se autofecundação das plantas. Plantas e frutos foram caracterizados preliminarmente com auxílio de descritores morfológicos. Resgatou-se acessos em todos os municípios visitados, sendo 112 de C. moschata e 50 de C. maxima. Verificou-se predominância do cultivo da espécie C. moschata bem como constatou-se grande variabilidade para vários descritores de planta e fruto nos acessos que foram caracterizados.

Palavras-chave: C. moschata. C. maxima. Coleta de acessos. Variabilidade.

\footnotetext{
*Corresponding author

${ }^{1}$ Received for publication in 10/28/2014; accepted in 09/21/2015.

Paper extracted from the doctoral thesis of the first author.

${ }^{2}$ Department of Plant Sciences, Universidade Federal Rural do Semi-Árido, Mossoró, RN, Brasil; gracekllagro@gmail.com, lindomarmaria@ufersa.edu.br.

${ }^{3}$ Department of Technology and Social Sciences, Universidade do Estado da Bahia, Juazeiro, BA, Brasil; manoelabiliomaq@gmail.com.
} 


\section{INTRODUCTION}

The genus Cucurbita consists of 24 species, of which five are cultivated (FERREIRA, 2008), highlighting the species Cucurbita moschata ((Duchesne ex Lam.) Duchesne ex Poiret) and $C$. maxima (Duchesne ex Lam.) (FERREIRA et al., 2006; SILVA et al., 2006). These species were originated in the Americas, being Mexico possibly the center of origin of C. moschata and South America as the center of C. maxima (RAMOS, 2003; FERREIRA, 2008).

In Brazil, these species were introduced by the Indians (QUEIROZ, 2004) and were part of their diet before the discovery and colonisation (HUE et al., 2009), being widely spread and grown in different regions of the country (FERREIRA, 2008; ROMANO et al., 2008). Particularly, in southern Brazil, there were introductions of $C$. argyrosperma, C. maxima and $C$. pepo held by European immigrants (QUEIROZ, 2004; FERREIRA, 2008). The cultivation of Cucurbita spp. has an important role regarding economic and social aspects as well as in human nutrition, due to its cooking versatility and nutritional value, animal feed, industrialisation and use for medicinal and ornamental purposes (CAMURCA-VASCONCELOS et al., 2005; BOITEUX et al., 2007; FERREIRA, 2008; AMBRÓSIO et al., 2012).

In Northeast Brazil, the species $C$. moschata and $C$. maxima are known popularly as 'jerimum de leite' (pumpkin) and 'jerimum caboclo' (squash), respectively, or simply 'jerimum' (pumpkin) (FERREIRA, 2008). A significant part of the cultivation of these species is carried out with the use of landraces adapted to the edaphoclimatic conditions of the region. These landraces have been cultivated for several generations with seeds selected and kept by the farmers, favouring the increase and maintenance of genetic variability (RAMOS, 2003; RAMOS et al., 2010; FERREIRA et al., 2011), thus becoming a rich genetic asset that ought to be preserved.

Some efforts have been undertaken in order to rescue germplasm of Cucurbita spp. in the Northeast region through collection expeditions. The collected accessions have been stored in the Active Bank of Cucurbitaceae Germplasm for the Brazilian Northeast (BAGC), located in Petrolina-PE (QUEIROZ et al., 1999; QUEIROZ, 2004). Nonetheless, among the states included in these expeditions, only Bahia and Maranhão had a higher representation of municipalities (QUEIROZ et al., 1999), since in those states there was greater infrastructure to support collections.

Family farming occurs in all states in the Northeast region, therefore germplasm collection expeditions in other locations become necessary, for rescuing new accessions and increase the variability in germplasm banks. Thus, the state of Rio Grande do Norte was chosen because it is one of the major producers of Cucurbita spp. in Northeast Brazil and also for being poorly represented in germplasm collection of these species in the past.

Therefore, this study aimed to rescue Cucurbita spp. germplasm from the family farms of the state of Rio Grande do Norte, to quantify the phenotypic variability and identify the main species grown.

\section{MATERIAL AND METHODS}

The expeditions of collection were carried out during the period from June 2010 to May 2014. The selection of sites for the collection of accessions had as criteria a representative selection of the major municipality which supply pumpkins and squashes to the state market (Rio do Fogo, Touros and Baraúna), based on the survey conducted in the Central Whole Sale fruits and vegetables Supply (CEASAs) of Natal and Mossoró and in eight municipalities in different microregions of the state (suppliers of fruits in the local market). In these areas, previous surveys were conducted with professionals from Institute of Technical Assistance and Rural Extension of Rio Grande do Norte (EMATER-RN) to identify family farmers. Data from the visited areas are detailed in Table 1.

During the collecting expeditions, samples of seeds and fruits of $C$. moschata and $C$. maxima were donated by the farmers when available. Each accession consisted of a fruit or about 20 seeds, following the recommendations of Vencovsky et al. (2007) for the size of the sample to be collected, adapted according to the requirement of these two species. When possible, the fruit samples were selected through visual observation of the existing phenotypic variability in the visited area, as recommended by Walter and Cavalcanti (2005).

All the samples obtained were sent to the Seed Technology Laboratory of the Federal Rural University of the Semi-Arid Region (UFERSA), Mossoró-RN, and the species were identified using the identification key for peduncle or seed characters (HEIDEN et al., 2007). For the samples obtained from seeds, they were packaged and held in properly identified paper bags and sealed with galvanised staples. For the samples obtained from fruits, the extraction of seeds of each fruit took place individually. The seeds were rinsed in running water, put in labelled tulle bags and dried under shade. After drying, the seeds were placed in paper bags, properly identified and closed with galvanised staples. All data of the samples were recorded individually in a germplasm collection book, and the seeds were stored in a cold chamber in the laboratory at a temperature of $16-18{ }^{\circ} \mathrm{C}$ and relative humidity of $50-55 \%$ in order to preserve the germplasm for multiplication. 
Table 1. Date and geographical and regional locations of the municipalities included in the expeditions of germplasm collections of pumpkins (Cucurbita spp.) from the state of Rio Grande do Norte.

\begin{tabular}{|c|c|c|c|c|c|}
\hline \multirow{2}{*}{$\begin{array}{l}\text { Collection sites } \\
\text { (municipalities) }\end{array}$} & \multirow{2}{*}{ Date of expeditions } & \multicolumn{2}{|c|}{ Geographical location* } & \multirow[t]{2}{*}{ Mesoregion } & \multirow[t]{2}{*}{ Microregion } \\
\hline & & $(\mathrm{S})$ & $(\mathrm{W})$ & & \\
\hline Apodi & $\begin{array}{l}1^{\mathrm{a}}-04.06 .2010 \\
2^{\mathrm{a}}-12.08 .2010 \\
3^{\mathrm{a}}-19.11 .2010 \\
4^{\mathrm{a}}-29.11 .2013\end{array}$ & $05^{\circ} 39^{\prime} 50^{\prime \prime}$ & $37^{\circ} 47^{\prime} 56^{\prime \prime}$ & Oeste Potiguar & $\begin{array}{l}\text { Chapada do } \\
\text { Apodi }\end{array}$ \\
\hline Baraúna & $\begin{array}{l}1^{\mathrm{a}}-18.08 .2010 \\
2^{\mathrm{a}}-08.11 .2010\end{array}$ & $05^{\circ} 04^{\prime} 48^{\prime \prime}$ & $37^{\circ} 37^{\prime} 01^{\prime \prime}$ & Oeste Potiguar & Mossoró \\
\hline Caraúbas & $1^{\mathrm{a}}-25.11 .2010$ & $05^{\circ} 47^{\prime} 34^{\prime \prime}$ & $37^{\circ} 33^{\prime} 25^{\prime \prime}$ & Oeste Potiguar & $\begin{array}{l}\text { Chapada do } \\
\text { Apodi }\end{array}$ \\
\hline Ceará Mirim & $1^{\mathrm{a}}-13.05 .2014$ & $05^{\circ} 38^{\prime} 02^{\prime \prime}$ & $35^{\circ} 25^{\prime} 33^{\prime \prime}$ & Leste Potiguar & Macaíba \\
\hline Cerro Corá & $1^{\mathrm{a}}-14.03 .2011$ & $06^{\circ} 02^{\prime} 45^{\prime \prime}$ & $36^{\circ} 20^{\prime} 45^{\prime \prime}$ & Central Potiguar & Serra de Santana \\
\hline Currais Novos & $\begin{array}{l}1^{\mathrm{a}}-28.10 .2010 \\
2^{\mathrm{a}}-15.03 .2011\end{array}$ & $06^{\circ} 15^{\prime} 39^{\prime \prime}$ & $36^{\circ} 30^{\prime} 54^{\prime \prime}$ & Central Potiguar & Seridó Oriental \\
\hline João Câmara & $1^{\mathrm{a}}-14.05 .2014$ & $05^{\circ} 32^{\prime} 16^{\prime \prime}$ & $35^{\circ} 49^{\prime} 12^{\prime \prime}$ & Agreste Potiguar & Baixa Verde \\
\hline Lagoa Nova & $1^{\mathrm{a}}-15.03 .2011$ & $06^{\circ} 09^{\prime} 64^{\prime \prime}$ & $36^{\circ} 46^{\prime} 93^{\prime \prime}$ & Central Potiguar & Serra de Santana \\
\hline Macaíba & $1^{\mathrm{a}}-15.05 .2014$ & $05^{\circ} 51^{\prime} 28^{\prime \prime}$ & $35^{\circ} 21^{\prime} 14^{\prime \prime}$ & Leste Potiguar & Macaíba \\
\hline Rio do Fogo & $\begin{array}{l}1^{\mathrm{a}}-16.09 .2010 \\
2^{\mathrm{a}}-21.12 .2010\end{array}$ & $05^{\circ} 16^{\prime} 22^{\prime \prime}$ & $35^{\circ} 22^{\prime} 58^{\prime \prime}$ & Leste Potiguar & Litoral Nordeste \\
\hline Touros & $1^{\mathrm{a}}-20.12 .2010$ & $05^{\circ} 11^{\prime} 56^{\prime \prime}$ & $35^{\circ} 27^{\prime} 39^{\prime \prime}$ & Leste Potiguar & Litoral Nordeste \\
\hline
\end{tabular}

*Geographical location of the municipal seats through Brazilian Institute of Geography and Statistic - IBGE (2012).

A subsample composed of approximately 20 seeds from each accession was transferred to the BAGC of the Brazilian Agricultural Research Corporation (Embrapa Semi-Arid), Petrolina-PE, where they were stored in a cold chamber at $10{ }^{\circ} \mathrm{C}$ and relative humidity of $40 \%$ for medium-term maintenance and preservation of the material for future studies of that germplasm.

Some accessions collected as fruits and a small number of the accessions obtained as seeds of the species $C$. moschata were multiplied using selfing of plants in order to keep the genetic integrity of the material. This experiment was carried out in the experimental field of the Department of Technology and Social Sciences (DTCS), Campus III, of the State University of Bahia (UNEB), Juazeiro-BA, during the period from June 2011 to October 2011.

During the multiplication trial, a preliminary characterisation of the $C$. moschata accessions was done using part of the descriptors as suggested by Esquinas-Alcazar and Gulick (1983), adapted for rind texture and added the descriptors emergency and height of seedlings, cotyledon width and length, number of fruits per plant, plant production, number of fixed fruits in controlled pollinations and soluble solids.

\section{RESULTS AND DISCUSSION}

Rescued Germplasm

One hundred sixty-two accessions of the 11 municipalities visited were rescued, 112 being of $C$. moschata and 50 of C. maxima (Table 2), showing that the cultivation of the landraces is dispersed in the state of Rio Grande do Norte. In the municipalities visited, at all sites it was observed the occurrence of the two species except for the municipalities of Baraúna and Ceará Mirim in which C. maxima was not found (Table 2). Therefore, this indicates that the cultivation of $C$. moschata is widespread, showing the same tendency of the Northeast Brazil as stated by Ramos et al. (2010). These authors also add that the fruits of this species are well accepted in the regional market.

Considering the material collected in the three main municipality fruit suppliers for wholesale market (CEASAs), in Baraúna only three accessions whereas in Rio do Fogo and Touros 42 and 19 were rescued, respectively (Table 2). It is likely that the market demands for uniform fruits have resulted in the replacement of these varieties by the commercial ones, causing strong genetic erosion in Baraúna as farmers abandoned their seeds and adopted commercial seeds. Large areas of monoculture of the cultivar 'Jacarezinho', intended for the national market was found as well as the varieties 'Atlas' and 'Caruacana' for export. In the other municipalities, the cultivation of landrace seeds from the state of Maranhão was observed, indicating the introduction of germplasm coming from other states.

Regarding the municipality fruit suppliers for the local market, Apodi and Currais Novos were those with the highest number of rescued accessions (Table 2), noting that in Currais Novos the number of accessions of $C$. moschata and $C$. maxima were almost equivalent. In the other municipalities, a few accessions of the two species were rescued (Table 2). It is likely that the low cultivation of these species in these municipalities occurred due to the heavy 
migration of farmers from rural areas to the urban areas and the total loss of seeds of landraces caused by long periods of drought.

The erosion of landraces has been reported by several authors (FERREIRA et al., 2006; PEREIRA et al., 2010), and it has aroused concern for breeders, as it reflects the reduction or loss of genetic variability hitherto available (BORÉM; MIRANDA,
2013). Therefore, measures aimed at recovering these varieties become more important, aiming to conserve the genetic diversity for current and future use in breeding programmes of the crop. Moreover, it is worth noting that, once collected, the germplasm must be properly stored in safe conditions, allowing conservation in the short, medium and long term (SILVA et al., 2006).

Table 2. Pumpkin (Cucurbita spp.) accessions collected in the municipalities of the state of Rio Grande do Norte.

\begin{tabular}{|c|c|c|c|c|c|c|}
\hline \multirow{3}{*}{$\begin{array}{l}\text { Collection sites } \\
\text { (municipalities) }\end{array}$} & \multirow{3}{*}{$\begin{array}{l}\text { Number of } \\
\text { expeditions }\end{array}$} & \multicolumn{4}{|c|}{ Number of accessions } & \multirow{3}{*}{$\begin{array}{c}\text { Total } \\
\text { collected }\end{array}$} \\
\hline & & \multicolumn{2}{|c|}{ Material type } & \multicolumn{2}{|c|}{ Species } & \\
\hline & & Seeds & Fruit & C. moschata & C. maxima & \\
\hline Apodi & 4 & 39 & 1 & 23 & 17 & 40 \\
\hline Baraúna & 2 & 3 & 0 & 3 & 0 & 3 \\
\hline Caraúbas & 1 & 5 & 0 & 1 & 4 & 5 \\
\hline Ceará Mirim & 1 & 0 & 2 & 2 & 0 & 2 \\
\hline Cerro Corá & 1 & 12 & 0 & 6 & 6 & 12 \\
\hline Currais Novos & 2 & 17 & 6 & 13 & 10 & 23 \\
\hline João Câmara & 1 & 5 & 0 & 4 & 1 & 5 \\
\hline Lagoa Nova & 1 & 4 & 0 & 2 & 2 & 4 \\
\hline Macaíba & 1 & 7 & 0 & 6 & 1 & 7 \\
\hline Rio do Fogo & 2 & 13 & 29 & 38 & 4 & 42 \\
\hline Touros & 1 & 2 & 17 & 14 & 5 & 19 \\
\hline Total & 17 & 107 & 55 & 112 & 50 & 162 \\
\hline
\end{tabular}

On the other hand, in collections in the municipalities of Apodi (local market) and Rio do Fogo (state market), the cultivation of species of Cucurbita has been identified, mainly C. moschata, for about 60 years. This implies exposing the seeds to the climatic conditions every year in which planting was possible and thus allowing natural selection in the cultivated types. As stated by Simmonds (1979), the continuous planting is the most important event of family farmers with respect to germplasm. Ramos et al. (2010) reported that the cultivation of species of Cucurbita spp. is related to the tradition of farmers in the Northeast of Brazil, who use their own seeds for the next planting season, a fact that was observed in all municipalities visited.

As for the type of collected material, there was a greater rescue of accessions from seeds compared to those from fruits in the eight municipalities (Table 2). It is likely that during the collecting expeditions in these municipalities farmers did not use their seeds due to the lack of rain, leaving them stored in their seed banks, and so it was not possible to collect fruits in these municipalities despite expeditions on the harvest season, and only seed collection was possible (Table 1). On the other hand, in the municipalities of Rio do Fogo and Touros, where the rescue of accessions from fruits prevailed (Table 2), the collections coincided with the harvest season in most production areas, which usually occur from December to January in Rio do Fogo and throughout the year in Touros, as they have irrigated crops.
Cultivation Systems

In the municipality of Baraúna, the cultivation of $C$. moschata in sole crop predominated with the use of commercial seeds, which can be of improved genotypes (registered cultivars) or not; the cultivation of landraces from the state of Maranhão also occurred. In the municipalities of Rio do Fogo and Touros, cultivation is carried out mainly with seeds of landraces of $C$. moschata either as sole crop or intercropped with maize (Zea mays L.), banana (Musa spp.) and/or coconut (Cocos nucifera L.). In those municipalities, irrigation systems (sprinkler and drip in Touros and Baraúna and subsurface in Rio do Fogo), mechanised cultivation and mineral fertilisers, with weekly application of chemicals are often used. Production is mainly intended for market. In the other municipalities visited, the landraces of Cucurbita spp. are grown mostly in home gardens or intercropped with beans (Phaseolus vulgaris L.) and maize, in receding cultivation near ponds and under rain-fed conditions, without frequent use of mineral fertilisers and pesticides; the fruits are usually destined for home consumption, animal feed or for sale of surplus in local markets, for school meals or for a middlemen.

\section{Seed Management By The Farmers}

During the collecting expeditions, it was observed that the seeds were stored in containers available on the property, such as plastic or glass 
bottles, aluminium cans and other containers, and they were mixed with ash, garlic buds, pepper, chemicals (powder). The containers, in some production units, were sealed with beeswax to control humidity. Despite these protection measures, it was found in some production units a partial or total loss of seeds of landraces, whether by pest attack (insects/rats) during storage or by loss of vigour probably due to poor packaging of the seeds. This loss of vigour was observed when seeds of some accessions were set in field experiments. In addition, seed losses may be increased by temporary flooding in production areas. In the municipality of Rio do Fogo, during years of heavy rains or lack of rain caused by long periods of drought in the rain-fed crops in other municipalities there may be crop losses, and therefore, offer potential risks for genetic erosion of this germplasm.

Phenotypic Variability Found

In the preliminary characterisation of the samples of C. moschata accessions, a wide variation in the descriptors of plants and fruits was found (Table 3). Other authors also have found great variability for species of the genus Cucurbita (NUEZ et al., 2000; PARIS; KABELKA, 2009). According to Romano et al. (2008), Cucurbita spp. is crosspollinated and show great variation in plant and fruit features. Therefore, the variability found in this study may be useful for breeding programmes of the crop, in order to develop cultivars adapted to the state of Rio Grande do Norte.

Table 3. Characterisation of Cucurbita moschata accessions collected in the state of Rio Grande do Norte.

\begin{tabular}{lc}
\hline Quantitative descriptor & Amplitude \\
\hline Seedling emergence $(\%)$ & 0 to 100 \\
Seedling height $(\mathrm{cm})$ & 1.75 to 5.76 \\
Cotyledon length $(\mathrm{cm})$ & 2.55 to 5.81 \\
Cotyledon width $(\mathrm{cm})$ & 1.8 to 3.65 \\
Number of fixed fruits in controlled pollinations & 0 to 7 \\
Fruit mass $(\mathrm{kg})$ & 1.4 to 5.4 \\
Number of fruits per plant & 1.4 to 6.1 \\
Plant production $(\mathrm{kg})$ & 4.5 to 14.8 \\
Fruit length $(\mathrm{cm})$ & 11.2 to 23.9 \\
Fruit diameter $(\mathrm{cm})$ & 14.5 to 23.5 \\
Pulp thickness $(\mathrm{cm})$ & 2.2 to 3.9 \\
Soluble solids $\left({ }^{\circ}\right.$ Brix) & 5.8 to 10.3 \\
\hline Qualitative descriptor & Categories \\
\hline Primary and secondary colour of the bark & Cream, green, yellow and orangish \\
Distribution of the secondary colour of the bark & Dots, stripes and marbled \\
Bark texture & Presence or absence of buds, presence or absence of roughness \\
Fruit shape & Globular, flattened, oblong, elliptical, heart-shaped, pear-shaped and \\
Pulp colour & elongated shape \\
\hline
\end{tabular}

\section{CONCLUSIONS}

Accessions were rescued in all the municipalities visited.

There is a predominance of cultivation of the species Cucurbita moschata.

The accessions collected in the state of Rio Grande do Norte exhibit great variability for various descriptors of plants and fruit.

\section{ACKNOWLEDGEMENTS}

The authors thank the technicians of the EMATER and the farmers of the municipalities visited for the contributions of samples of seeds and fruits for the achievement of this work.

\section{REFERENCES}

AMBRÓSIO, C. L. B. et al. Flocos desidratados de abóbora na prevenção de carência de vitamina $\mathrm{A}$ em pré-escolares de uma creche. Revista Nutrição, Campinas, v. 25, n. 1, p. 57-64, 2012.

BOITEUX, L. S. et al. 'Brasileirinha': cultivar de abóbora (Cucurbita moschata) de frutos bicolores com valor ornamental e aptidão para consumo verde. Horticultura Brasileira, Brasília, DF, v. 25, n. 1, p. 103-106, 2007.

BORÉM, A. et al. Melhoramento de Plantas. 6 ed. Viçosa, MG: UFV, 2013. 523 p.

CAMURÇA-VASCONCELOS, A. L. F. et al. Validação de plantas medicinais com atividade antihelmíntica. Revista Brasileira de Plantas Medicinais, Botucatu, v. 7, n. 3, p. 97-106, 2005.

ESQUINAS-ALCAZAR, J. T. et al. Genetic resources of cucurbitaceae. 1 ed. Rome: IBPGR, 1983. $101 \mathrm{p}$. 
FERREIRA, M. A. J. F. Abóboras e morangas. In: BARBIERI, R. L.; STUMPF, E. R. T. (eds.). Origem e evolução de plantas cultivadas. Brasília: Embrapa Informação Tecnológica, 2008. cap. 3, p. 61-88.

FERREIRA, M. A. J. F. et al. Diagnóstico sobre variedades locais de abóboras em áreas de agricultores familiares. 1 ed. Petrolina, PE: Embrapa Semiárido, 2011. 19 p. (Boletim de Pesquisa e Desenvolvimento, 88).

FERREIRA, M. A. J. F. et al. Mapeamento da distribuição geográfica e conservação dos parentes silvestres e variedades crioulas de Cucurbita. In: Parentes silvestres das espécies de plantas cultivadas. Brasília, DF: Ministério do Meio Ambiente, 2006. cap. 5, p. 24-29.

HEIDEN, G. et al. Chave para a identificação das espécies de abóboras (Cucurbita, Cucurbitaceae) cultivadas no Brasil. 1 ed. Pelotas, RS: Embrapa Clima Temperado, 2007. 32 p. (Documentos, 197).

HUE, S.M. et al. Delícias do descobrimento: a gastronomia brasileira no século XVI. 1 ed. Rio de Janeiro: Zahar, 2009. 207 p.

INSTITUTO BRASILEIRO DE GEOGRAFIA E ESTASTÍSTICA (IBGE). Divisão territorial brasileira 2012: listagem de municípios do Rio Grande do Norte. Disponível em: <http:// www.ibge.gov.br/estadosat/>. Acesso em: 04 mar. 2012.

NUEZ, F. et al. Cucurbita spp. and Lagenaria siceraria collection at the Center for Conservation and Breeeding of Agricultural Biodiversity (CCMAV), Polytechnical University of Valencia. Cucurbit Genetics Cooperative Report, Raleigh, NC, n. 23, p. 60-61, 2000

PARIS, H. S.; KABELKA, E. Gene list for Cucurbita species. Cucurbit Genetics Cooperative Report, Raleigh, NC. n. 31-32, p. 44-69, 2009.

PEREIRA, M. G.; SILVA, F. F.; PEREIRA, T. N. S. Recursos genéticos vegetais e o melhoramento de plantas. In: PEREIRA, T. N. S. (ed.). Germoplasma: conservação, manejo e uso no melhoramento de plantas. Viçosa, MG: Arca, 2010. cap. 5, p. 141-176.

QUEIROZ, M. A. Germplasm of cucurbitaceae in Brazil. Crop Breeding e Applied Biotechnology, Viçosa, MG, v. 4, n. 4, p. 377-383, 2004.

QUEIROZ, M. A. et al. Situação atual e prioridades do banco ativo de germoplasma (BAG) de cucurbitáceas do Nordeste brasileiro. Horticultura
Brasileira, Brasília, DF, v. 17, p. 25-29, 1999 (Suplemento).

RAMOS, S. R. R. Diversidade genética baseada em marcadores moleculares AFLP e indicação de coleção nuclear de Cucurbita moschata para o nordeste do Brasil. 2003. 102f. Tese (Doutorado em Produção Vegetal) - Universidade Estadual do Norte Fluminense Darcy Ribeiro, Campos dos Goytacazes, RJ, 2003.

RAMOS, S. R. R. et al. Aspectos técnicos do cultivo de abóbora na região nordeste do Brasil. 1 ed. Aracaju, SE: Embrapa Tabuleiros Costeiros, 2010. 36 p. (Documentos, 154).

ROMANO, C. M. et al. Polinização manual de abóboras. 1 ed. Pelotas, RS: Embrapa Clima Temperado. 2008. 25 p. (Documentos, 225).

SILVA, D. B. et al. Conservação de germoplasma de Cucurbita spp. a longo prazo no Brasil. 1 ed. Brasília, DF: Embrapa Recursos Genéticos e Biotecnologia, 2006. 12 p. (Boletim de Pesquisa e Desenvolvimento, 135).

SIMMONDS, N.W. Principles of crop improvement. New York: Longman. 1979. 408 p.

VENCOVSKY, R. et al. Amostragem em recursos genéticos vegetais. In: NASS, L. L. (Ed.). Recursos genéticos vegetais. 1 ed. Brasília, DF: Embrapa Recursos Genéticos e Biotecnologia, 2007. cap. 7, p. 231-280

WALTER, B.M.T. et al. Fundamentos para coleta de germoplasma vegetal. 1 ed. Brasília, DF: Embrapa Recursos Genéticos e Biotecnologia, 2005. $778 \mathrm{p}$. 